\title{
Karakteristik Permen Keras (Hard Candy) Wortel dan Lemon
}

\section{The Characteristics of Carrot and Lemon Hard Candy}

\section{Fadhilah Pratiwi'1a, Intan Kusumaningrum¹, Lia Amalia1}

${ }^{1}$ Jurusan Teknologi Pangan dan Gizi, Fakultas Ilmu Pangan Halal Universitas Djuanda Bogor Jl. Tol Ciawi No.1, Kotak Pos 35 Ciawi, Bogor 16720

aKorespondensi: Fadhilah Pratiwi, E-mail: pratiwi.fadhilah11@gmail.com

(Diterima oleh Dewan Redaksi : 02 - 08 - 2019)

(Dipublikasikan oleh Dewan Redaksi : 30 - 10 - 2019)

\begin{abstract}
Carrot is one of vagatable that contains plenty of nutritions and as the source of $\beta$-carotene. Lemon is one of fruit that contains plenty of nutritions and as the source of Vitamin C. Both of carrot and lemon have a lot of nutritional content for human body, but still has very limited utilization. Product innovation for carrot and lemon is needed in order to give diverse utilization of carrot and lemon. Hard candy is a product that contains sucrose, glucose, water as the main raw materials, and has hard, transparant, glossy texture. Making hard candy that contain carrot and lemon is one of ways to utilize carrot and lemon and give beneficial nutritions to human body. This study aims to find preffered formulation to make carrot and lemon hard candy. This hard candy is made with three ratio comparation sucrose and glucose that calculated in grams (75:25, 70:30, 65:25), and two comparation on time of cooking (5mins and $7 \mathrm{mins}$ ). The analysis performed included organoleptic (quality of sensory and hedonic test), content of chemistry test, such as moisture content, ash, vitamin $C$, invert sugar, and $B$-carotene. The selected hard candy of carrot and lemon is A1 (75:25) B1 (5mins), with moisture content $1,31 \%$, ash $0,145 \%$, invert sugar $44 \%$, vitamin $C 0,835 \%$, and $\beta$ carotene $0,675 \%$.
\end{abstract}

Keywords : hard candy, carrot, lemon.

\section{ABSTRAK}

Wortel adalah salah satu jenis sayuran yang banyak mengandung nutrisi dan sebagai sumber beta karoten. Lemon adalah salah satu jenis buah yang banyak mengandung nutrisi dan sebagai sumber vitamin C. Wortel dan lemon, kedua bahan ini mempunyai banyak kandungan gizi yang berguna untuk tubuh namun masih kurang pemanfaatannya. Inovasi produk untuk wortel dan lemon dibutuhkan dalam rangka untuk memberikan variasi pemanfaatan produk dari wortel dan lemon. Permen keras adalah produk yang berbahan dasar sukrosa, glukosa, air, dan mempunyai tekstur yang keras, transparan, dan berkilau. Pembuatan permen keras dengan bahan dasar wortel dan lemon merupakan salah satu cara untuk memanfaatkan wortel dan lemon dan memberikan manfaat nutrisi kepada konsumen. Penelitian ini bertujuan untuk menentukan formulasi yang tepat untuk membuat permen keras wortel dan lemon. Permen keras ini dibuat dengan tiga rasio perbandingan sukrosa dan glukosa yang dihitung dalam gram $(75: 25,70: 30,65: 25)$, dan dua perbandingan pada lama waktu pemasakan ( 5 menit, dan 7 menit). Analisa yang dilakukan meliputi analisa organoleptik (uji sensori dan uji hedonik), uji kimia seperti uji kadar air, kadar abu, vitamin C, gula reduksi, beta karoten. Permen keras wortel dan lemon terpilih adalah permen A1 (75:25) B1 (5menit), dengan kadar air 1,31\%, abu 0,145\%, gula reduksi 44\%, vitamin C 0,835\%, dan beta-karoten $0,675 \%$.

Kata kunci: permen keras, wortel, lemon.

Pratiwi , Fadhilah, Intan Kusumaningrum, Lia Amalia. 2019. Karakteristik Permen Keras (Hard

Candy) Wortel dan Lemon. Jurnal Agroindustri Halal 5(2): $228 \quad-\quad 237$.




\section{PENDAHULUAN}

Indonesia merupakan negara agraris yang mempunyai hasil pertanian melimpah baik sayuran maupun buah-buahan. Meningkatnya kebutuhan masyarakat Indonesia terhadap pemenuhan standar gizi baik untuk anak, remaja, dan dewasa selalu menjadi perhatian agar Indonesia menghasilkan generasi yang sehat dan cerdas.

Vitamin merupakan salah satu zat gizi yang sangat diperlukan untuk menjaga kesehatan tubuh. Mengonsumsi sayur seperti wortel (Daucus carota) dan lemon (Citrun lemon) merupakan salah satu langkah baik untuk memenuhi kebutuhan gizi terutaman vitamin $\mathrm{A}$ dan vitamin $\mathrm{C}$.

Umumnya wortel diolah menjadi bahan pangan seperti sayur dan jus wortel, padahal wortel yang mengandung vitamin dan nilai gizi yang sangat tinggi. Kurangnya inovasi pengolahan wortel menjadikan wortel kurang diminati masyarakat padahal pengolahan wortel lebih lanjut bisa menjadikan wortel lebih mudah dikonsumsi dan menaikkan harga pasar wortel. Beta karoten yang merupakan sumber vitamin $\mathrm{A}$ merupakan zat gizi tertinggi yang terkandung dalam wortel, namun bukan hanya beta karoten wortel juga tinggi akan kandungan gizi seperti vitamin $\mathrm{C}$, serat, fosfor, zat besi, dan kalsium (Dwiwati, 2014).

Jeruk lemon merupakan buah yang sering digunakan dalam pembuatan minuman segar dikarenakan rasanya yang asam dan segar, dan sebagai sumber vitamin C. Jeruk lemon mempunyai rasa asam yang khas yang bersumber dari asam askorbat dan merupakan prekursor dari vitamin C. Pada tubuh vitamin C sangat berguna sebagai antioksidan untuk menangkal radikal bebas, mencegah kanker, dan memperkuat daya tahan tubuh (Wijaya, Y.A. 2008).

Dengan banyaknya kandungan gizi wortel dan jeruk lemon maka dilakukan pengolahan lebih lanjut salah satunya dengan mengolah komoditi menjadi produk pangan berupa permen keras (hard candy). Hard candy adalah jenis permen yang mempunyai tekstur keras dan penampakan bening serta berkilau (glossy). Bahan utama dalam pembuatan hard candy adalah sukrosa, sirup glukosa, dan air (Ramadhan, 2012). Penambahan wortel dan jeruk lemon pada hard candy, diharapkan permen keras ini dapat menjadi alternatif untuk diserfikasi pangan dengan memberikan nilai gizi bagi masyarakat untuk menjaga kesehatan tubuh dengan adanya vitamin $\mathrm{A}$ dan vitamin C dari wortel dan lemon. Tujuan dari penelitian ini adalah untuk mengetahui perbandingan sukrosa dan glukosa yang tepat, mengetahui lama waktu pemasakan yang tepat, dan untuk mengetahui kandungan kadar air, kadar abu, gula reduksi, vitamin $\mathrm{C}$ dan betakaroten pada permen keras wortel dan lemon. Penambahan jeruk lemon pada permen wortel diharapkan dapat menutupi langu dari wortel dan menjadikan permen wortel lebih bisa diterima oleh masyarakat.

\section{MATERI DAN METODE}

\section{Bahan dan Alat}

Bahan baku yang digunakan dalam pembuatan permen keras (hard candy) wortel dan lemon adalah wortel, lemon, air, glukosa, dan sukrosa. Adapun bahan tambahan lainnya adalah asam sitrun, sert bahan-bahan kimia untuk analisis kimia.

Alat-alat yang digunakan untuk analisis kimia yaitu juicer, timbangan analitik, sudit, sendok, gelas ukur, thermometer, pisau, mangkuk, gelas kecil, kain saring, saringan, pipet tetes, dan alat-alat penunjang lainnya untuk analisis kimia.

\section{Waktu dan Tempat Penelitian}

Penelitian ini dilaksanakan pada bulan MeiOktober 2018 di Laboratorium Universitas Djuanda Bogor dan Laboratorium Saraswanti Indo Genetech Bogor. 


\section{Pembuatan Ekstrak Lemon}

\section{Persiapan dan Pembuatan Ekstrak}

\section{Pembuatan Ekstrak Wortel}

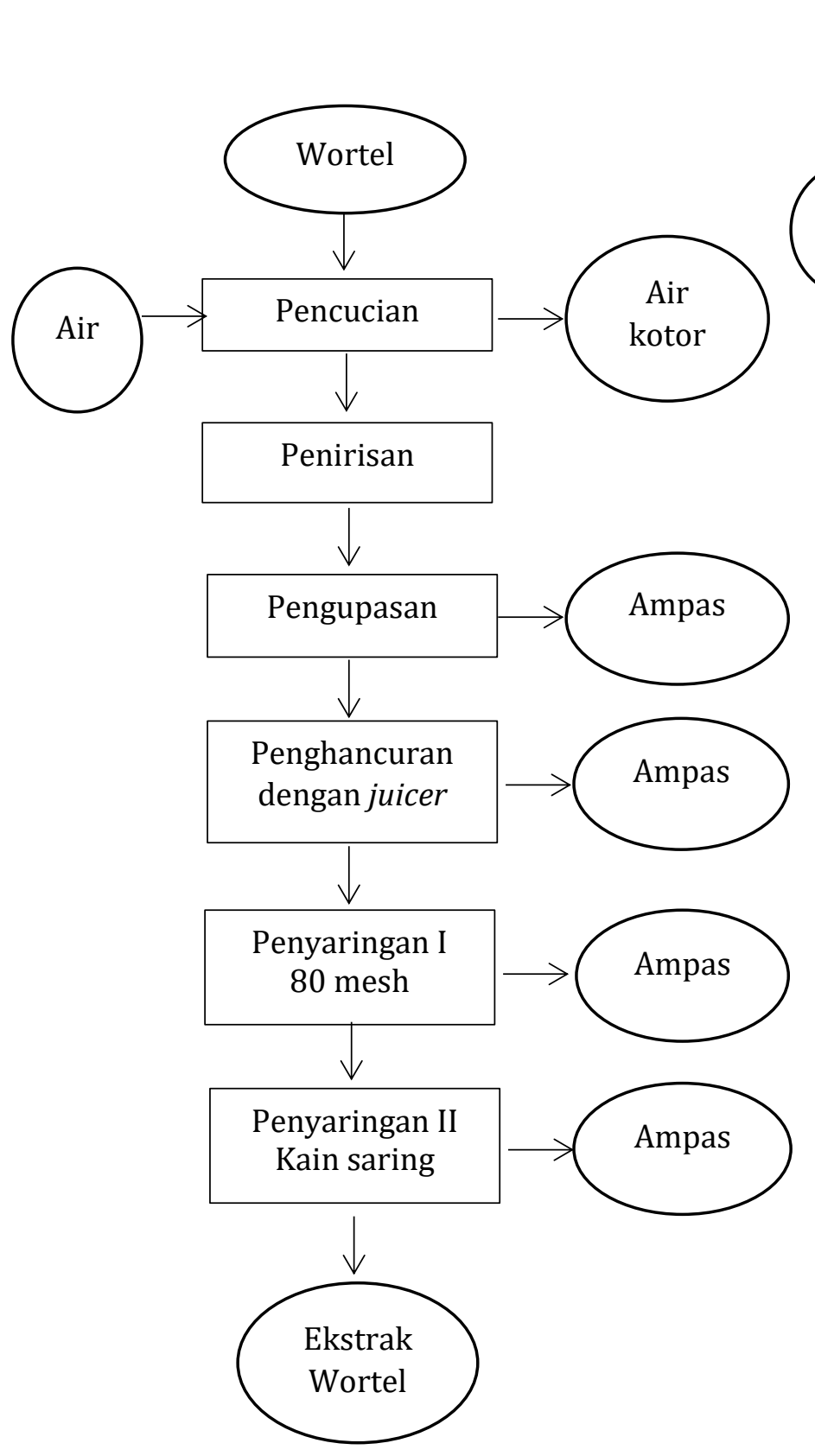

Gambar 1. Pembuatan ekstrak wortel

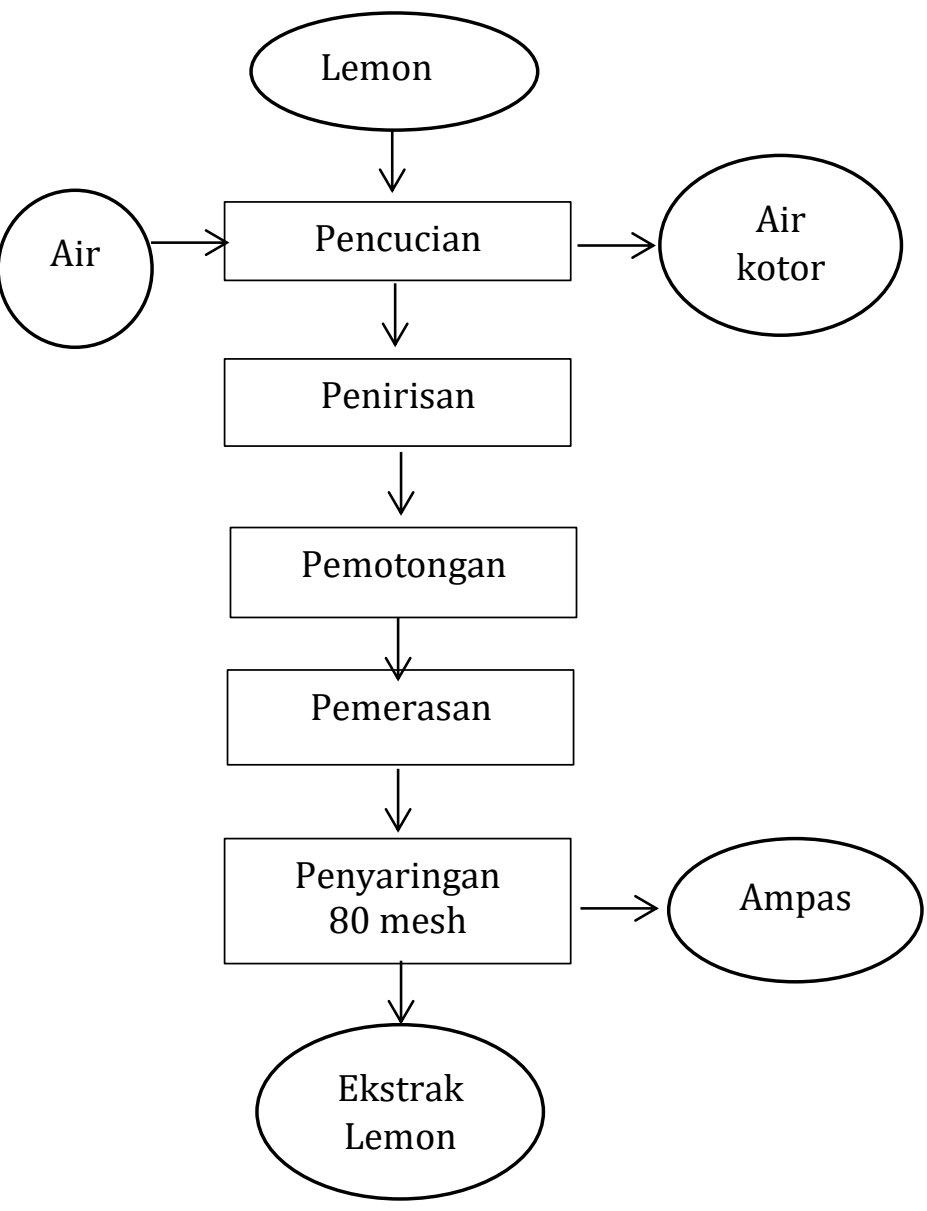

Gambar 2. Pembuatan ekstrak lemon

\section{Tahap I}

Dilakukan pembuatan produk dengan 2 faktor, yaitu faktor A, perbandingan sukrosa dan glukosa dalam berat gram $(b / b)$ dengan perbandingan 75:25 (A1), 70:30 (A2), 65:35 (A3). Faktor B, waktu lama pemasakan 5menit (B1), dan 7 menit (B2). 


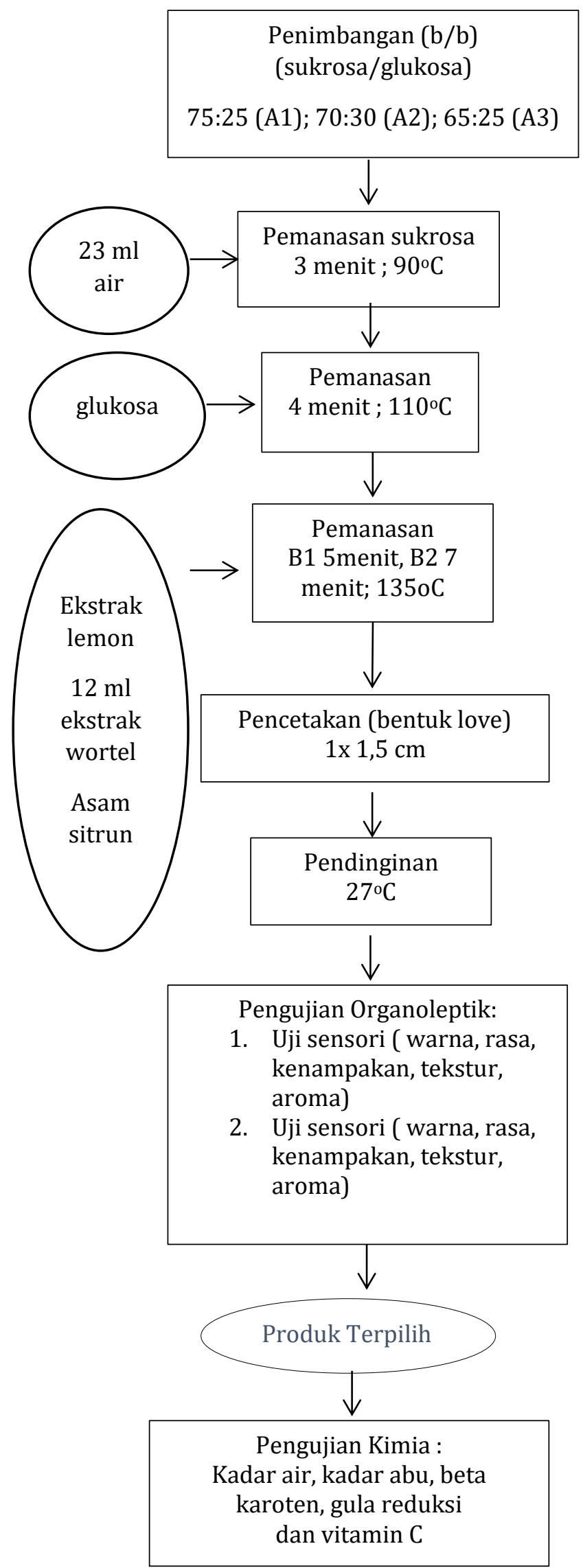

Gambar 3. Pembuatan permen keras wortel dan lemon

\section{Rancangan Percobaan}

Rancangan Percobaan yang digunakan dalam penelitian yang di aplikasikan pada Tahap 2 adalah Rancangan Acak Lengkap (RAL) dua faktor. Faktor-faktor yang dipelajari pada penelitian tahap 2 yaitu Faktor A perbandingan sukrosa dan glukosa dalam gram $(\mathrm{b} / \mathrm{b})$ dengan 3 taraf, yaitu $\mathrm{A} 1$ (75:25), A2 (70:30), A3 (65:35). Faktor B waktu lama pemasakan dengan 2 taraf yaitu B1 (5menit), B2 (7 menit). Model rancangan yang digunakan pada tahap 1 sebagai berikut :

$Y=\mu+\alpha i+\beta j+(\alpha \beta) i j+\varepsilon$

Keterangan:

Yijk : Nilai pengamatan pada faktor konsentrasi ke - i, Lama waktu pemasakan ke-j , ulangan ke- $\mathrm{k}$

$\mu \quad$ : Rataan umum

$\alpha \mathrm{i} \quad$ : Pengaruh utama konsentrasi ke-i

$\beta \mathrm{j}$ : Pengaruh utama lama waktu pemasakan ke- $\mathrm{j}$

$(\alpha \beta) \mathrm{ij}$ : Komponen interaksi konsentrasi ke i dan waktu lama pemasakan ke-j

$\varepsilon$ i: Pengaruh acak yang menyebar normal $(0,1,2)$

i : Banyaknya faktor A $(1,2,3)$

j $\quad$ : Banyaknya faktor B $(1,2)$

$\mathrm{k}$ : Banyaknya ulangan $(1,2)$

Seluruh perlakukan penelitian ini dilakukan dengan dua kali ulangan.

\section{Analisis Produk}

Analisa dilakukan dengan menggunakan SPSS 23 untuk mengetahui pengaruh konsentrasi glukosa dengan sukrosa dan lama waktu pemasakan terhadap permen keras rortel dan lemon. Jika nilai $\mathrm{p}<0,05$, maka perlakuan 
dinyatakan berbeda nyata dan dilakukan uji lanjut dengan menggunakan Uji Duncan.

\section{HASIL DAN PEMBAHASAN}

\section{Mutu Sensori}

Mutu sensori permen keras wortel dan lemon meliputi lima parameter yang diuji yaitu, aroma, rasa, warna, kenampakan, dan tekstur.

\section{Parameter Aroma}

Hasil mutu sensori aroma permen keras wortel dan lemon berkisar antara 4,7374,190 dengan deskripsi dari arah kiri tidak terdapat aroma asing ke arah kanan terdapat aroma asing.

Tabel 1. Hasil uji sensoris aroma permen keras wortel dan lemon

\begin{tabular}{cccc}
\hline $\begin{array}{c}\text { Sukrosa : } \\
\text { Glukosa } \\
\text { (gram)(A) }\end{array}$ & $\begin{array}{c}\text { Waktu } \\
\text { pemasakan } \\
\text { (menit) (B) }\end{array}$ & $\begin{array}{c}\text { Perbandingan } \\
\text { Sukrosa dan } \\
\text { Glukosa (A) }\end{array}$ \\
\cline { 2 - 3 } & 5 & 7 & \\
\hline $75: 25$ & $4,190^{\mathrm{a}}$ & $4,446^{\mathrm{a}}$ & $4,326^{\mathrm{a}}$ \\
$70: 30$ & $4,208^{\mathrm{a}}$ & $4,481^{\mathrm{a}}$ & $4,344^{\mathrm{a}}$ \\
$65: 35$ & $4,737^{\mathrm{a}}$ & $4,414^{\mathrm{a}}$ & $4,575^{\mathrm{a}}$ \\
\hline Waktu & $4,348^{\mathrm{a}}$ & $4,447^{\mathrm{a}}$ & \\
pemasakan & & & \\
(menit) (B) & & & \\
\hline
\end{tabular}

Ket : notasi huruf yang berbeda menunjukkan berbeda nyata pada taraf $5 \%$

Berdasarkan analisis sidik ragam (ANOVA) menunjukkan bahwa perbandingan sukrosa dan glukosa tidak berpengaruh nyata terhadap aroma permen wortel dan lemon $(p>0,05)$, dan lama pemasakan tidak berpengaruh nyata terhadap aroma permen keras wortel dan lemon $\quad(p>0,05)$ Interaksi antar perbandingan sukrosa dan glukosa dengan waktu lama pemasakan tidak berpengaruh nyata terhadap aroma permen keras wortel dan lemon $(p>0,05)$.

\section{Parameter Rasa}

Hasil mutu sensori parameter rasa permen keras wortel dan lemon berkisar antara 4,444-3,383 dari arah kiri tidak terdapat rasa asing hingga ke kanan terdapat rasa asing.

Tabel 2. Hasil uji sensoris rasa permen keras wortel dan lemon

\begin{tabular}{cccc}
\hline $\begin{array}{c}\text { Sukrosa : } \\
\begin{array}{c}\text { Glukosa } \\
\text { (gram)(A) }\end{array}\end{array}$ & \multicolumn{2}{c}{$\begin{array}{c}\text { Waktu } \\
\text { pemasakan } \\
\text { (menit) (B) }\end{array}$} & $\begin{array}{c}\text { Perbandingan } \\
\text { Sukrosa dan } \\
\text { Glukosa (A) }\end{array}$ \\
\cline { 2 - 3 } 5 & 5 & 7 & \\
\hline $75: 25$ & $4,152^{\mathrm{a}}$ & $4,094^{\mathrm{a}}$ & $4,1233^{\mathrm{a}}$ \\
$70: 30$ & $3,571^{\mathrm{a}}$ & $4,444^{\mathrm{a}}$ & $3,908^{\mathrm{a}}$ \\
$65: 35$ & $3,383^{\mathrm{a}}$ & $3,980^{\mathrm{a}}$ & $3,6815^{\mathrm{a}}$ \\
\hline Waktu & $3,684^{\mathrm{a}}$ & $4,173^{\mathrm{b}}$ & \\
pemasakan & & & \\
(menit) (B) & & & \\
\hline
\end{tabular}

Ket : notasi huruf yang berbeda menunjukkan berbeda nyata pada taraf $5 \%$

Berdasarkan analisis sidik ragam (ANOVA) menunjukkan rasio perbandingan sukrosa dan glukosa tidak berpengaruh nyata terhadap rasa permen keras wortel dan lemon ( $>00,05)$. Lama pemasakan berpengaruh nyata terhadap rasa permen keras wortel dan lemon $(p<0,05)$. Interaksi antar sukrosa dan glukosa dengan lama waktu pemasakan tidak berpengaruh terhadap rasa permen keras wortel dan lemon $(p>0,05)$.

\section{Parameter Warna}

Hasil mutu sensori parameter warna permen keras wortel dan lemon berkisar antara 4,907-5,700, dari arah kiri oranye terang hingga ke kanan oranye gelap.

Berdasarkan uji sidik ragam (ANOVA) perbandingan sukrosa dan glukosa berpengaruh nyata terhadap warna permen keras wortel dan lemon $(p<0,05)$. Lama pemasakan tidak berpengaruh nyata terhadap warna permen keras wortel dan lemon $(p>0,05)$. 
Tabel 3. Hasil uji sensoris warna permen keras wortel dan lemon

\begin{tabular}{|c|c|c|c|}
\hline \multirow{2}{*}{$\begin{array}{c}\text { Sukrosa : } \\
\text { Glukosa } \\
\text { (gram)(A) }\end{array}$} & \multicolumn{2}{|c|}{$\begin{array}{c}\text { Waktu } \\
\text { pemasakan } \\
\text { (menit) (B) }\end{array}$} & \multirow{2}{*}{$\begin{array}{c}\text { Perbandingan } \\
\text { Sukrosa dan } \\
\text { Glukosa (A) }\end{array}$} \\
\hline & 5 & 7 & \\
\hline $75: 25$ & $5,700^{a}$ & $5,652^{a}$ & $5,6759^{a}$ \\
\hline $70: 30$ & $5,313^{a}$ & $5,365^{\mathrm{a}}$ & $5,3390^{\mathrm{ab}}$ \\
\hline $65: 35$ & $4,907^{a}$ & $5,096^{\mathrm{a}}$ & $5,0015^{b}$ \\
\hline
\end{tabular}

Waktu $\quad 5,307^{a} \quad 5,371^{a}$

pemasakan

(menit) (B)

Ket : notasi huruf yang berbeda menunjukkan berbeda nyata pada taraf $5 \%$

Interaksi antar sukrosa dan glukosa tidak memiliki pengaruh nyata terhadap warna permen keras wortel dan lemon ( $p>0,05)$.

\section{Parameter Kenampakan}

Hasil mutu sensori parameter kenampakan permen keras wortel dan lemon berkisar antara 4,749-6,175, dari arah kiri tidak transparan dan tidak glossy hingga ke kanan transparan dan glossy.

Tabel 4. Hasil uji sensoris kenampakan permen keras wortel dan lemon

\begin{tabular}{|c|c|c|c|}
\hline \multirow[t]{2}{*}{$\begin{array}{l}\text { Sukrosa: } \\
\text { Glukosa } \\
\text { (gram)(A) }\end{array}$} & \multicolumn{2}{|c|}{$\begin{array}{c}\text { Waktu } \\
\text { pemasakan } \\
\text { (menit) (B) }\end{array}$} & \multirow[t]{2}{*}{$\begin{array}{c}\text { Perbandingan } \\
\text { Sukrosa dan } \\
\text { Glukosa (A) }\end{array}$} \\
\hline & 5 & 7 & \\
\hline $75: 25$ & $5,723^{a}$ & $6,175^{a}$ & $5,949 \mathrm{a}$ \\
\hline 70:30 & $5,338^{a}$ & $5,086^{a}$ & $5,212^{b}$ \\
\hline $65: 35$ & $5,342^{\mathrm{a}}$ & $4,749^{a}$ & $5,046^{b}$ \\
\hline $\begin{array}{c}\text { Waktu } \\
\text { pemasakan } \\
\text { (menit) (B) }\end{array}$ & $5,468^{a}$ & 5,337 a & \\
\hline
\end{tabular}

Ket : notasi huruf yang berbeda menunjukkan berbeda nyata pada taraf $5 \%$

Berdasarkan uji sidik ragam (ANOVA) perbandingan sukrosa dan glukosa, memiliki pengaruh yang nyata terhadap kenampakan permen keras wortel dan lemon $(\mathrm{p}<0,05)$. Lama pemasakan tidak berpengaruh nyata terhadap kenampakan permen keras wortel dan lemon ( $p>0,05)$. Interaksi antar sukrosa dan glukosa dengan lama waktu pemasakan tidak berpengaruh nyata terhadap kenampakan permen wortel dan lemon ( $p>0,05)$.

\section{Parameter Tekstur}

Hasil mutu tekstur permen keras berkisar antara 5,599-6,629, dari arah kiri tidak keras hingga ke kanan keras.

Tabel 5. Hasil uji sensoris tekstur permen keras wortel dan lemon

\begin{tabular}{cccc}
\hline $\begin{array}{c}\text { Sukrosa: } \\
\begin{array}{c}\text { Glukosa } \\
\text { (gram)(A) }\end{array}\end{array}$ & $\begin{array}{c}\text { Waktu } \\
\text { pemasakan } \\
\text { (menit) (B) }\end{array}$ & \multirow{2}{*}{$\begin{array}{c}\text { Perbandingan } \\
\text { Sukrosa dan } \\
\text { Glukosa (A) }\end{array}$} \\
\cline { 2 - 3 } & 5 & 7 & \\
\hline $75: 25$ & $6,629^{\mathrm{a}}$ & $6,545^{\mathrm{a}}$ & $6,587^{\mathrm{a}}$ \\
$70: 30$ & $6,420^{\mathrm{a}}$ & $6,252^{\mathrm{a}}$ & $6,336^{\mathrm{b}}$ \\
$65: 35$ & $5,599^{\mathrm{a}}$ & $6,305^{\mathrm{a}}$ & $5,952^{\mathrm{b}}$ \\
\hline Waktu & $6,216^{\mathrm{a}}$ & $6,367^{\mathrm{a}}$ & \\
pemasakan & & & \\
(menit) (B) & & & \\
\hline
\end{tabular}

Ket : notasi huruf yang berbeda menunjukkan berbeda nyata pada taraf $5 \%$

Berdasarkan uji sidik ragam (ANOVA) perbandingan sukrosa dan glukosa, memiliki pengaruh yang nyata terhadap tekstur permen keras wortel dan lemon $(\mathrm{p}<0,05)$. Lama pemasakan tidak berpengaruh nyata terhadap tekstur permen keras wortel dan lemon ( $p>0,05)$. Interaksi antar sukrosa dan glukosa dengan lama waktu pemasakan tidak berpengaruh nyata terhadap tekstur permen wortel dan lemon ( $p>0,05)$.

\section{Uji Hedonik}

Uji hedonik pada penelitian ini bertujuan untuk mengetahu kesukaan panelis terhadap produk permen kers wortel dan lemon yang meliputi kesukaan dari aroma, rasa, warna, kenampakan, dan tekstur.

\section{Parameter Aroma}

Hasil hedonik parameter aroma permen keras wortel dan lemon berkisar antara 5,947-6,277 yang mengarah ke arah suka. 
Tabel 6. Hasil uji hedonik aroma permen keras wortel dan lemon

\begin{tabular}{|c|c|c|c|}
\hline \multirow{2}{*}{$\begin{array}{l}\text { Sukrosa : } \\
\text { Glukosa } \\
\text { (gram)(A) }\end{array}$} & \multicolumn{2}{|c|}{$\begin{array}{c}\text { Waktu } \\
\text { pemasakan } \\
\text { (menit) (B) }\end{array}$} & \multirow[t]{2}{*}{$\begin{array}{c}\text { Perbandingan } \\
\text { Sukrosa dan } \\
\text { Glukosa (A) }\end{array}$} \\
\hline & 5 & 7 & \\
\hline $75: 25$ & $6,248^{a}$ & $6,277^{a}$ & $6,2625^{a}$ \\
\hline 70:30 & $6,267 a$ & $6,086^{\mathrm{a}}$ & $6,1763^{a}$ \\
\hline $65: 35$ & $6,056^{\mathrm{a}}$ & 5,947 a & $6,0015^{\mathrm{a}}$ \\
\hline $\begin{array}{c}\text { Waktu } \\
\text { pemasakan } \\
\text { (menit) (B) }\end{array}$ & $6,190^{a}$ & $6,103^{a}$ & \\
\hline
\end{tabular}

Ket : notasi huruf yang berbeda menunjukkan berbeda nyata pada taraf $5 \%$

Berdasarkan uji sidik ragam (ANOVA) perbandingan sukrosa dan glukosa, tidak memiliki pengaruh yang nyata terhadap kesukaan panelis terhadap aroma permen keras wortel dan lemon ( $p>0,05)$. Lama pemasakan tidak berpengaruh nyata terhadap kesukaan panelis terhadap aroma permen keras wortel dan lemon ( $p>0,05)$. Interaksi antar sukrosa dan glukosa dengan lama waktu pemasakan tidak berpengaruh nyata pada kesukaan panelis terhadap aroma permen wortel dan lemon $(p>0,05)$.

\section{Parameter Rasa}

Hasil hedonik parameter rasa permen keras wortel dan lemon berkisar antara 5,7766,815 yang mengarah ke arah suka.

Tabel 7. Hasil uji hedonik rasa permen keras wortel dan lemon

\begin{tabular}{cccc}
\hline $\begin{array}{c}\text { Sukrosa : } \\
\text { Glukosa } \\
\text { (gram)(A) }\end{array}$ & $\begin{array}{c}\text { Waktu } \\
\text { pemasakan } \\
\text { (menit) (B) }\end{array}$ & \multirow{2}{\text{Perbandingan}}{$\begin{array}{c}\text { Sukrosa dan } \\
\text { Glukosa (A) }\end{array}$} \\
\cline { 2 - 3 } & 5 & 7 & \\
\hline $75: 25$ & $6,110^{\mathrm{a}}$ & $6,815^{\mathrm{a}}$ & $6,463^{\mathrm{a}}$ \\
$70: 30$ & $6,369^{\mathrm{a}}$ & $5,899^{\mathrm{a}}$ & $6,134^{\mathrm{a}}$ \\
$65: 35$ & $6,192^{\mathrm{a}}$ & $5,776^{\mathrm{a}}$ & $5,984^{\mathrm{a}}$ \\
\hline Waktu & $6,224^{\mathrm{a}}$ & $6,163^{\mathrm{a}}$ & \\
pemasakan & & & \\
(menit) (B) & & & \\
\hline
\end{tabular}

Ket : notasi huruf yang berbeda menunjukkan berbeda nyata pada taraf $5 \%$
Berdasarkan uji sidik ragam (ANOVA) perbandingan sukrosa dan glukosa, tidak memiliki pengaruh yang nyata terhadap kesukaan panelis terhadap rasa permen keras wortel dan lemon $(p>0,05)$. Lama pemasakan tidak berpengaruh nyata pada kesukaan panelis terhadap rasa permen keras wortel dan lemon $(p>0,05)$. Interaksi antar sukrosa dan glukosa dengan lama waktu pemasakan tidak berpengaruh nyata pada kesukaan panelis terhadap rasa permen wortel dan lemon $(p>0,05)$.

\section{Parameter Warna}

Hasil hedonik parameter warna permen keras wortel dan lemon berkisar antara 5,540-7,063 yang mengarah ke arah suka.

Tabel 8. Hasil uji hedonik warna permen keras wortel dan lemon

\begin{tabular}{cccc}
\hline $\begin{array}{c}\text { Sukrosa : } \\
\begin{array}{c}\text { Glukosa } \\
\text { (gram)(A) }\end{array}\end{array}$ & \multicolumn{2}{c}{$\begin{array}{c}\text { Waktu } \\
\text { pemasakan } \\
\text { (menit) (B) }\end{array}$} & \multirow{2}{*}{$\begin{array}{c}\text { Perbandingan } \\
\text { Sukrosa dan } \\
\text { Glukosa (A) }\end{array}$} \\
\cline { 2 - 3 } & 5 & 7 & \\
\hline $75: 25$ & $6,808^{\mathrm{a}}$ & $7,063^{\mathrm{b}}$ & $5,7678^{\mathrm{a}}$ \\
$70: 30$ & $6,383^{\mathrm{a}}$ & $6,117^{\mathrm{a}}$ & $6,250^{\mathrm{a}}$ \\
$65: 35$ & $5,995^{\mathrm{a}}$ & $5,540^{\mathrm{a}}$ & $6,9352^{\mathrm{b}}$ \\
\hline Waktu & $6,395^{\mathrm{a}}$ & $6,240^{\mathrm{a}}$ & \\
pemasakan & & & \\
(menit) (B) & & & \\
\hline
\end{tabular}

Ket : notasi huruf yang berbeda menunjukkan berbeda nyata pada taraf $5 \%$

Berdasarkan uji sidik ragam (ANOVA) perbandingan sukrosa dan glukosa, berpengaruh yang nyata terhadap kesukaan panelis terhadap warna permen keras wortel dan lemon $(\mathrm{p}<0,05)$. Lama pemasakan tidak berpengaruh nyata pada kesukaan panelis terhadap warna permen keras wortel dan lemon $(p>0,05)$. Interaksi antar sukrosa dan glukosa dengan lama waktu pemasakan tidak berpengaruh nyata pada kesukaan panelis terhadap warna permen wortel dan lemon ( $p>0,05)$. 


\section{Parameter Kenampakan}

Hasil hedonik parameter kenampakan permen keras wortel dan lemon berkisar antara 5,922-6,881yang mengarah ke arah suka.

Tabel 9. Hasil uji hedonik kenampakan permen keras wortel dan lemon

\begin{tabular}{cccc}
\hline $\begin{array}{c}\text { Sukrosa : } \\
\text { Glukosa } \\
\text { (gram)(A) }\end{array}$ & \multicolumn{2}{c}{$\begin{array}{c}\text { Waktu } \\
\text { pemasakan } \\
\text { (menit) (B) }\end{array}$} & \multirow{2}{*}{$\begin{array}{c}\text { Perbandingan } \\
\text { Sukrosa dan } \\
\text { Glukosa (A) }\end{array}$} \\
\cline { 2 - 3 } & 5 & 7 & \\
\hline $75: 25$ & $6,727^{\mathrm{a}}$ & $6,881^{\mathrm{b}}$ & $6,804^{\mathrm{a}}$ \\
$70: 30$ & $6,605^{\mathrm{a}}$ & $5,980^{\mathrm{a}}$ & $6,292^{\mathrm{ab}}$ \\
$65: 35$ & $6,187^{\mathrm{a}}$ & $5,922^{\mathrm{a}}$ & $6,055^{\mathrm{b}}$ \\
\hline Waktu & $6,506^{\mathrm{a}}$ & $6,261^{\mathrm{a}}$ & \\
pemasakan & & & \\
(menit) (B) & & & \\
\hline
\end{tabular}

Ket : notasi huruf yang berbeda menunjukkan berbeda nyata pada taraf $5 \%$

Berdasarkan uji sidik ragam (ANOVA) perbandingan sukrosa dan glukosa, berpengaruh yang nyata terhadap kesukaan panelis terhadap kenampakan permen keras wortel dan lemon $(\mathrm{p}<0,05)$. Lama pemasakan tidak berpengaruh nyata pada kesukaan panelis terhadap kenampakan permen keras wortel dan lemon ( $p>0,05)$. Interaksi antar sukrosa dan glukosa dengan lama waktu pemasakan tidak berpengaruh nyata pada kesukaan panelis terhadap warna permen wortel dan lemon $(p>0,05)$.

\section{Parameter Tekstur}

Hasil hedonik parameter tekstur permen keras wortel dan lemon berkisar antara 5,938-6,610 yang mengarah ke arah suka.

Tabel 10. Hasil uji hedonik tekstur permen keras wortel dan lemon

\begin{tabular}{|c|c|c|c|}
\hline \multirow{2}{*}{$\begin{array}{l}\text { Sukrosa : } \\
\text { Glukosa } \\
\text { (gram)(A) }\end{array}$} & \multicolumn{2}{|c|}{$\begin{array}{c}\text { Waktu } \\
\text { pemasakan } \\
\text { (menit) (B) }\end{array}$} & \multirow[t]{2}{*}{$\begin{array}{c}\text { Perbandingan } \\
\text { Sukrosa dan } \\
\text { Glukosa (A) }\end{array}$} \\
\hline & 5 & 7 & \\
\hline $75: 25$ & $6,574^{a}$ & $6,610^{b}$ & $6,592^{a}$ \\
\hline $70: 30$ & $6,268^{a}$ & $6,230^{a}$ & $6,249 a$ \\
\hline $65: 35$ & $5,938^{a}$ & $5,955^{a}$ & $5,946^{b}$ \\
\hline
\end{tabular}

Waktu
pemasakan
(menit) (B)

Ket : notasi huruf yang berbeda menunjukkan berbeda nyata pada taraf $5 \%$

Berdasarkan uji sidik ragam (ANOVA) perbandingan sukrosa dan glukosa, tidak berpengaruh yang nyata terhadap kesukaan panelis terhadap tekstur permen keras wortel dan lemon ( $p>0,05)$. Lama pemasakan tidak berpengaruh nyata terhadap kesukaan panelis terhadap tekstur permen keras wortel dan lemon ( $p>0,05)$. Interaksi antar sukrosa dan glukosa dengan lama waktu pemasakan tidak berpengaruh nyata pada kesukaan panelis terhadap tekstur permen wortel dan lemon ( $p>0,05)$.

\section{Penentuan Produk Terpilih}

Penentuan produk terpilih dilakukan berdasarkan hasil dari uji sensori dan uji hedonik. Berdasarkan hasil uji hedonik dan sensori dengan parameter aroma, rasa warna, kenampakan, dan tekstur perbandingan sukrosa dan glukosa yang paling banyak terpilih adalah formulasi A1 yaitu perbandingan sukrosa:glukosa 75:25. Berdasarkan uji sensori rasa, lama pemasakan yang terpilih adalah pemasakan B1 (5menit) yang mempunyai arah lebih kuat terhadap tidak mempunyai rasa asing, sedangkan pada uji sensori dan hedonik perbedaan lama waktu pemasakan tidak memberikan pengaruh nyata terhadap aroma warna, kenampakan, tekstur hard candy wortel dan lemon.

Dari hasil yang didapat, makan produk terpilih dari permen keras (hard candy) wortel dan lemon yaitu produk dengan perlakuan A1B1 yang terdiri dari perbandingan sukrosa dan glukosa (75:25) dan lama waktu pemasakan 5 menit.

\section{Analisis Produk Terpilih}

Produk terpilih dari permen keras (hard candy) wortel dan lemon dilakukan uji kimia 
yaitu uji kadar air, kadar abu, gula reduksi, vitamin $\mathrm{C}$, dan betakaroten.

Tabel 11. Hasil Uji Kimia Produk Terpilih Produk A1B1

\begin{tabular}{lc}
\hline \multicolumn{1}{c}{ Parameter Uji } & Jumlah \\
\hline Kadar Air (\%) & 1,32 \\
Kadar Abu (\%) & 0,145 \\
Gula Reduksi (\%) & 44 \\
Vitamin C (\%) & 0,835 \\
Beta Karoten (mg/kg) & 0,675 \\
\hline
\end{tabular}

\section{Kadar Air}

Nilai rata-rata kadar air pada permen keras wortel dan lemon adalah 1,32\%. Menurut Engka 2016, sukrosa mempunyai sifat yang mampu mengikat air dan komponen lainnya. Penambahan ekstrak wortel dan ekstrak lemon mempengaruhi kadar air permen keras. Kadar air pada hard candy termasuk rendah. Semakin banyak sukrosa yang ditambahkan maka semakin kecil kadar air yang dihasilkan. Penambahan ekstrak wortel dan lemon, suhu, dan lama waktu pemasakan memberikan pengaruh terhadap kadar air permen keras wortel dan lemon. Kadar air memengaruhi penampakan dan tekstur dari hard candy. Jika air terlalu tinggi maka menyebabkan permen tidak dapat mengeras dan tidak dapat membentuk hard candy (Ramadhan, 2012).

\section{Kadar Abu}

Nilai rata-rata kadar abu pada permen keras wortel dan lemon adalah 0,145\%. Kadar abu pada bahan pangan berkaitan dengan kandungan mineral pada bahan pangan tersebut. Menurut Winarno (1992) dalam Wahyuni (2012), semakin banyak konsentrasi sukrosa dan glukosa yang ditambahkan, maka kandungan mineral makin tinggi. Mineral pada sukrosa yaitu kalsium dan fosfor. Kadar abu berkorelasi dengan kandungan mineral pada umumnya semakin besar kadar mineral yang besar mempunyai kadar abu yang tinggi (Ramadhan, 2012). Penambahan ekstak wortel dan ekstrak lemon juga akan menambah kandungan mineral yang terkandung pada permen keras wortel dan lemon.

\section{Gula Reduksi}

Nilai rata-rata gula reduksi pada permen keras wortel dan lemon adalah 44\%. Kadar gula reduksi ditentukan oleh rasio sukrosa dan glukosa. Semakin banyak sukrosa yang ditambahkan maka semakin banyak sukrosa yang tereduksi menjadi glukosa dan fruktosa, sehingga gula reduksi meningkat (Engka, 2016). Menurut Desrosier (1989) dalam Hasniarti (2012), dengan adanya asam selama pemasakan sukrosa akan terhidrolisis menjadi gula invert yaitu glukosa dan fruktosa yang merupakan gula reduksi. Pada pembuatan permen keras wortel dan lemon, produk terpilih mempunyai rasio sukrosa yang paling tinggi yaitu 75 gram dengan glukosa 25gram. Tingginya sukrosa menyebabkan banyaknya gula yang terinversi menjadi glukosa dan fruktosa. Penambahan lemon pada permen keras yang bersifat asam juga mempercepat inversi sukrosa. Faktor asam dan sukrosa yang tinggi ini yang menyebabkan kadar gula reduksi tinggi pada permen keras wortel dan lemon.

\section{Vitamin C}

Nilai rata -rata vitamin C pada permen keras wortel dan lemon adalah 0,835\%. Vitamin C pada permen keras ini didapat dari penambahan lemon. Vitamin $\mathrm{C}$ merupakan senyawa yang sangat mudah larut dalam air, mempunyai sifat asam dan sifat pereduksi yang kuat. Vitamin C bersifat sangat sensitif terhadap pengaruh luar dan dapat menyebabkan kerusakan. Vitamin C memiliki sifat mudah larut dalam air, mudah teroksidasi dan proses tersebut 
dipercepat oleh panas, sinar, alkali, enzim, oksidator, serta katalis besi dan tembaga (Yulianti, 2008). Faktor pemanasan mempunyai pengaruh yang besar pada penurunan kadar Vitamin $\mathrm{C}$ pada pembuatan permen keras wortel dan lemon.

\section{Betakaroten}

Nilai rata-rata Beta Karoten pda permen keras wortel dan lemon adalah 0,675 mg/kg. Beta karoten pada permen keras ini didapat dari penambahan wortel. Beta karoten merupakan provitamin A yang banyak terdapat dalam bahan-bahan nabati terutama sayur dan buah. Provitamin A mempunyai sifat yang mudah teroksidasi karena udara dan akan mudah rusak dengan pemanasan suhu tinggi (Yulianti, 2008). Kadar beta karoten yang rendah pada permen keras wortel dan lemon ini dikarenakan pada proses pembuatan permen keras dilakukan pemanasan sampai suhu $135^{\circ} \mathrm{C}$, sedangkan provitamin A hanya bisa bertahan dan stabil sampai suhu $60^{\circ} \mathrm{C}$. Hal ini yang menyebabkan rendahnya kadar beta karoten pada permen keras wortel dan lemon.

\section{KESIMPULAN DAN SARAN}

\section{Kesimpulan}

Berdasarkan uji organoleptik sensori dan hedonik, produk terpilih untuk permen keras wortel dan lemon adalah produk dengan formulasi A1B1 yaitu perbandinan sukrosa dan glukosa 75:25 (A1) dan lama waktu pemasakan 5menit (B1). Produk terpilih memiliki kadar air sebesar 1,32\%, kadar abu 0,145\%, gula reduksi $44 \%$, vitamin C 0,835\% dan kadar betakaroten $0,675 \mathrm{mg} / \mathrm{kg}$.

\section{Saran}

Perlu dilakukan penelitian lanjutan untuk didapatkan ekstrak wortel dan lemon yang lebih pekat agar diperoleh permen hard candy wortel dan lemon dengan mutu sensori yang lebih baik.

\section{DAFTAR PUSTAKA}

Dwiwati, R. 2014. Pemanfaatan Ekstrak Wortel (Daucus Carota) dan Buah Wuluh (Curcubita moschata). Universitas Muhammadiyah Surakarta. Surakarta.

Engka, D. L. 2016. Pengaruh Konsesntrasi Sukrosa dan Sirup Glukosa

Terhadap Sifat Kimia dan Sensoris Permen Keras Belimbing Wuluh.

Hasniarti. 2012. Studi Pembuatan Buah Dengen (Dillenia serrata Thumb) [skripsi]. Jurusan Teknologi Pangan Fakultas Pertanian. Universitas Hassanudin, Makassar.

Ramadhan. 2012. Pembuatan Permen Hard Candy yang Mengandungn Propolis Sebagai Permen Kesehatan Gigi [Skripsi]. Universitas Indonesia, Jakarta.

Wahyuni. T., Lubis, L. M., Ginting, S., 2014. Pengaruh Perbandungn Buah Markisa dengan Pepaya dan Konsentrasi Gula Terhadap Mutu Permen (Hard Candy). J.Rekayasa Pangan dan Pertanian. Vol 2 No. 2

Wijaya, Y.A. 2008. Daya Analgesik sari jeruk buah lemon pada mencit putih betina [Skripsi]. Universitas Sanata Dharma, Yogyakarta. 